
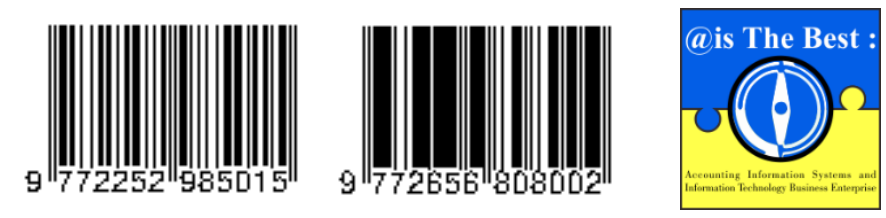

ais The Best :

Accounting Information Systems and

Information Technology Business Enterprise

Volume 04, Nomor 02 (2019) Hal. 166-180

ISSN: 2252-9853 (Print) | ISSN: 2656-808X (Online)

https://ojs.unikom.ac.id/index.php/aisthebest/index

Terakreditasi Peringkat 4, SK No.: 28/E/KPT/2019

DOI: $\underline{10.34010 / \text { aisthebest.v4i02.2704 }}$

\title{
Faktor Penentu Cost of Equity di Industri Properti dan Real Estate
}

\author{
Suryanto $^{1}$, Sarah Maulidina ${ }^{2}$ \\ ${ }^{1,2}$ Departemen Adminsitrasi Bisnis, Universitas Padjadjaran \\ email : suryanto@unpad.ac.id
}

\section{Keywords: \\ Cost of equity; asymmetric Information; firm size; disclosure}

\begin{abstract}
This study aims to determine the factors that determine the cost of equity in the property and real estate industry. The research method used in this research is descriptive and verification. Sources of data obtained from secondary data published. The data used is panel data obtained from 14 property and real estate companies for a period of 3 years. The analysis technique uses multiple regression and the coefficient of determination. To test the factors that affect the cost of equity using the $t$ test and $F$ test. The results of the study state that the factors that affect the cost of equity are firm siza and disclosure, while asymmetric information is not a factor affecting the cost of equity. However, if carried out simultaneously asymmetric information, firm siza and disclosure are factors that affect the cost of equity.
\end{abstract}

\begin{abstract}
Abstrak
Penelitian ini bertujuan untuk menentukan faktor-faktor yang menentukan cost of equity di industri properti dan real estate. Metode penelitian yang digunakan dalam penelitian ini adalah deskriptif dan verifikatif. Sumber data diperoleh dari data sekunder yang dipublish. Data yang digunakan merupakan data panel yang diperoleh dari 14 perusahaan properti dan real etate selama kurun waktu 3 tahun. Teknik analisis menggunakan regresi berganda dan koefisien determinasi. Untuk menguji faktorfaktor yang mempengaruhi cost of equity menggunakan uji t dan uji F. Hasil penelitian menyatakan bahwa faktor-faktor yang mempengaruhi cost of equity adalah firm siza dan disclousure, sedangkan asymmetric information bukan faktor yang mempengaruhi cost of equity. Namun jika dilakukan secara simultan asymmetric information, firm siza dan disclousure merupakan faktor yang berpengaruh terhadap cost of equity.
\end{abstract}

\section{Pendahuluan}

Perkembangan sektor property dan real estate di suatu negara menjadi cermin bahwa perkekonomian negara tersebut sedang tumbuh. Sektor property diyakini mampu memberikan efek multiplier terhadap pertumbuhan sektor usaha yang lainnya [1]. Adanya perkembangan di sektor ini menyebabkan banyak calon investor yang berminat menginvestasikan dananya.

Perusahaan dapat memanfaatkan antusias investor dengan menggali sumber financing dari masyarakat. Adapun modal yang diperoleh dari kebijakan financing dapat digunakan untuk mengembangkan program-program perusahaan. Kebijakan financing yang mungkin bisa dilakukan oleh perusahaan dapat berupa tambahan liability atau memperbesar equity [2]. Kebijakan financing berupa tambahan liabilities ataupun memperbesar equity, masing-masing memiliki risiko.

Pemilihan ekuitas dalam kebijakan financing tidak terlepas dari pertimbangan biaya modal (cost of capital) yang harus dikeluarkan perusahaan. Selain karena lebih murah, penggunaan equity juga memiliki risiko yang lebih rendah dibandingkan menggunakan liabilities [3]. Biaya modal sendiri (cost of equity) merupakan tingkat pengembalian yang diharapkan oleh seorang investor atas investasi yang mereka tanamkan dalam perusahaan. 
Penentuan besar kecilnya cost of equity dipengaruhi oleh beberapa faktor. Botosan (1997) menyatakan bahwa pengungkapan (disclosure) yang lebih tinggi berpengaruh pada cost of equity yang lebih rendah [4]. Titman, et al, (2011) menyatakan bahwa penentu utama cost of equity dilihat dari risikonya [5]. Sementara menurut pendapat Gode dan Mohanram (2001) bahwa cost of equity dipengaruhi oleh return votality, leverage, information environmental (seperti informasi asimetris dan disclosure), industry effect, dan earning volatility [6]. Pendapat senada dikemukakan Pratt dan Grabownski (2010) yang menjelaskan bahwa cost of equity selain ditentukan oleh faktor-faktor tersebut juga ditentukan oleh ukuran perusahaan (firm size) [7].

Beberapa penelitian lainnya yang berkaitan denga faktor-faktor yang menentukan cost of equity menghasilkan kesimpulan yang berbeda. Komalasari dan Baridwan (2001) menyatakan bahwa faktor-faktor yang menentukan besar kecilnya cost of equity adalah informasi asimetris dan ukuran perusahaan [8]. Terdapat hubungan positif antara informasi asimetris dengan cost of equity. Hal ini berarti bahwa semakin kecil informasi asimetris yang terjadi maka semakin kecil pula cost of equity yang ditanggung perusahaan. Selain itu, hasil pengujian juga menunjukkan hubungan negatif antara ukuran perusahaan (firm size) dengan cost of equity sebagai akibat penurunan asimetri informasi antara perusahaan besar dan kecil.

Hasil penelitian Mardiyah (2002) menyatakan bahwa faktor-faktor yang menentukan cost of equity antara lain disclosure dan informasi asimetris [9]. Namun, Murwaningsari (2012) menyatakan bahwa selain disclousure dan informasi asimetris, faktor firm size juga ikut menentukan cost of equity [10]. Omran and Pointon (2004) menyatakan bahwa faktor yang menentukan cost of equity adalah pertumbuhan dan size perusahaan [11]. Hasil penelitian yang berbeda dari Albanez, et al (2010) bahwa yang menentukan cost of capital hanya size perusahaan, sedangkan informasi asimetris tidak berpengaruh secara signifikan [12].

Peneliti lainnya, Indayani (2013) mengatakan bahwa faktor yang menentukan cost of equity adalah informasi asimetris dan voluntary disclosure [13]. Sedangkan Ningsih dan Ariani (2016) dalam penelitiannya menyatakan bahwa cost of equity dipengaruhi oleh kualitas audit, sedangkan asimetri informasi dan disclousure tidak mempengaruhi cost of equity [14].

Hasil empiris diatas menemukan adaya hasil penelitian yang tidak konsisten dari beberapa faktor yang menentukan cost of equity mendorong peneliti melakukan penelitian kembali. Kemudian hasil empiris juga hanya menguji faktor-faktor yang mempengaruhi cost of equity secara parsial. Penelitian ini dapat memberikan kontribusi yang lebih komprehensif yaitu dengan menguji faktor-faktor yang mempengaruhi cost of equity secara simultan. Beberapa faktor yang dapat mempengaruhi cost of equity dalam penelitian ini akan dibatasi hanya 3 (tiga) faktor, yaitu informasi asimetris, ukuran perusahaan dan pengungkapan. Adapun alasan peneliti memilih ketiga faktor tersebut karena dalam penelitian sebelumnya, faktor-faktor tersebut memiliki kesimpulan penelitian yang berbeda. Peneliti memilih sektor industri properti dan real estate karena industri tersebut memiliki tingkat pertumbuhan indeks harga saham yang paling tinggi. Adapun hasil penelitian ini dapat berguna bagi para investor mengenai beberapa faktor yang dapat mempengaruhi cost of equity suatu perusahaan.

\section{Kerangka Teoritis}

\section{Cost of Equity}

Konsep biaya modal (cost of equity) seperti yang dikemukakan Modigliani dan Miller (1958) merupakan biaya yang dikeluarkan untuk membiayai sumber pendanaan (source of financing) [15]. Merekalah yang pertama kali mendefinisikan cost of equity dalam literatur keuangan yang berkaitan dengan risiko investasi saham perusahaan. Ross, Westerfield, Jaffe (2012) menyatakan biaya 
@ is The Best: Accounting Information Systems and Information Technology Business Enterprise ISSN: 2252-9853 (Print) | ISSN: 2656-808X (Online)

modal ekuitas sebagai berikut: "Whenever a firm has extra cash, it can take one of two action. It can pay out the cash immediately as a dividend. Alternatively the firm can invest the extra cash in a project. In project, paying out tyhe future cash flows of the project as devidend. That all project that of the firm have the same risk in that case, one could say the the discount rate is equal to the cost of capital for the firm as the whole and if the firm is all equity, the discount rate equal to the firm's cost of equity capital." [16]. Perusahaan dapat mendapatkan modal ekuitasnya dengan 2 (dua) cara, yaitu dengan menggunakan laba ditahan dan menerbitkan emisi saham baru [17].

Cost of equity sangat penting untuk diketahui, karena memiliki banyak manfaat. Beberapa manfaat seperti yang dijelaskan Weston \& Brigham (1977), antara lain: untuk memaksimalkan nilai perusahaan, dasar pengambilan keputusan yang tepat di bidang penganggaran barang modal, dan berbagai macam keputusan lainnya yang dapat diambil oleh manajer keuangan [18].

Pengukuran cost of emity dipengaruhi oleh model penilaian perusahaan yang digunakan. Model penilaian perusahaan menurut Utami (2006) [19], antara lain :

a. Constant Growth Valuation Model

Model ini dikenal dengan sebutan Gordon Model. Dasar pemikiran yang digunakan adalah bahwa nilai saham dengan nilai tunai (present value) dari semua deviden yang akan diterima di masa yang akan datang (diasumsikan pada tingkat pertumbuhan konstan) dalam waktu yang tidak terbatas. Model ini dikenal dengan sebutan Gordon model. Nilai saham biasa dengan pertumbuhan normal diformulasikan sebagai berikut:

$$
P_{o}=\frac{D_{1}}{(K s-g)}
$$

\section{Keterangan:}

Po = Nilai saham biasa perusahaan

$\mathrm{D}_{1} \quad=$ Dividen pada tahun pertama

Ks $\quad=$ Tingkat hasil atau pengembalian minimum saham biasa

$\mathrm{g} \quad=$ Tingkat pertumbuhan dividen

\section{b. Capital Asset Pricing Model (CAPM)}

Biaya modal saham biasa adalah tingkat return yang diharapkan oleh investor sebagai kompensasi atas risiko yang tidak dapat didiversifikasi yang diukur dengan beta. Menurut pendekatan CAPM, pendapatan yang diharapkan dari investasi saham ditentukan oleh pendapatan investasi bebas risiko dan premi risiko pasar. Besarnya premi risiko pada pendekatan ini ditentukan oleh besar kecilnya risiko sistematis $(\beta)$ saham. Adapun besarnya pendapatan saham diukur dengan rumus :

$$
\mathrm{R} i t=\mathrm{R} f+\beta i .(\mathrm{R} m t-\mathrm{R} f)
$$

\section{Keterangan :}

Rit $\quad$ Pendapatan saham i pada periode $\mathrm{t}$

Rf = Pendapatan investasi bebas risiko

$\mathrm{R} m t=$ Pendapatan pasar pada periode $\mathrm{t}$

$\beta i \quad=$ Koefisien risiko sistematis saham 
Pendapatan yang diharapkan dapat dirumuskan sebagai berikut :

$\mathrm{E}(\mathrm{R} \imath)=\mathrm{R} f+[\mathrm{E}(\mathrm{R} m t)-\mathrm{R} f]$ karena $\mathrm{E}(\mathrm{R} \imath)=$ ke dengan demikian,

$\mathrm{k} e \quad=\mathrm{R} f+{ }_{\beta} i\{\mathrm{E}(\mathrm{R} m t)-\mathrm{R} f\}$

c. Model Edward Bell Ohlson

Model ini digunakan untuk mengestimasi nilai perusahaan dengan mendasarkan pada nilai buku ekuitas ditambah dengan nilai tunai dari abnormal return. Cost of equity dihitung berdasarkan tingkat diskonto yang dipakai investor untuk menilai tunaikan future cash flow [20].

$$
P_{t}=y_{t}+(1+r)^{-t} E t\left\{x_{\mathrm{t}+1}-(r) y_{\mathrm{t}+t-1}\right\}
$$

Keterangan :

$\mathrm{Pt} \quad=$ Harga saham pada tahun $\mathrm{t}$

$\mathrm{B}_{\mathrm{t}} \quad=$ Nilai buku per lembar saham tahun $\mathrm{t}$

$\mathrm{x}_{\mathrm{t}+1} \quad=$ Laba per lembar saham pada tahun ${ }_{\mathrm{t}+1}$

$\mathrm{r} \quad=$ Efektifitas Biaya modal

Untuk mengestimasikan laba per saham pada tahun $\mathrm{t}_{\mathrm{t}+1}$ digunakan model Random $W$ alk sebagai berikut :

$$
\mathrm{E}\left(\mathrm{x}_{\mathrm{t}+1}\right)=\mathrm{x}_{\mathrm{t}+} \delta
$$

Keterangan :

$\mathrm{E}\left(\mathrm{x}_{\mathrm{t}+1}\right)=$ Estimasi laba per lembar saham pada tahun ${ }_{\mathrm{t}+1}$

$\mathrm{x}_{\mathrm{t}} \quad=$ Laba per lembar saham aktual pada tahun $\mathrm{t}$

$\delta \quad=$ Drift term yang merupakan rata-rata perubahan laba per lembar saham

Dengan demikian estimasi biaya modal pada persamaan (1) dapat disederhanakan menjadi sebagai berikut

$$
\mathrm{P}_{\mathrm{t}}=\mathrm{B}_{\mathrm{t}}+(1+\mathrm{r})^{-1}\left[\mathrm{x}_{\mathrm{t}+1}-\mathrm{rB} \mathrm{B}_{\mathrm{t}}\right]
$$

Keterangan :

$\mathrm{X}_{\mathrm{t}+1} \quad=$ Laba per saham tahun $\mathrm{t}+1$ yang diestimasi dengan model random walk seperti persamaan (2).

Setelah disederhanakan secara matematik maka persamaan (3) menjadi :

$$
\begin{aligned}
& \left(\mathrm{P}_{\mathrm{t}}-\mathrm{B}_{\mathrm{t}}\right)(1+\mathrm{r})=\left(\mathrm{x}_{\mathrm{t}+1}-\mathrm{r} \mathrm{B}_{\mathrm{t}}\right) \\
& r=\frac{\left(B_{t}+x_{t-1}-P_{t}\right)}{P_{t}}
\end{aligned}
$$

\section{Faktor-faktor yang Mempengaruhi Cost of Equity}

Salah satu unsur kebijakan keuangan perusahaan adalah berkaitan dengan aspek financing. Aspek ini berkaitan dengan bagaimana perusahaan memenuhi kebutuhan sumber permodalan yang akan digunakan untuk membiayai perusahaan. Sumber pembiyaan dapat diperoleh dari hutang ataupun ekuitas. Pemilihan altenatif sumber pembiayaan didasarkan pada pertimbangan biaya modal (cost of capital) dan risiko (risk). Ada beberapa faktor yang dapat mempengaruhi besar kecilnya biaya modal, yaitu information environment (seperti asymmetric information and disclosure), size, return volatility, leverage, industry effect, dan earning volatility [6], [7]. 
@is The Best: Accounting Information Systems and Information Technology Business Enterprise ISSN: 2252-9853 (Print) | ISSN: 2656-808X (Online)

Berikut uraian masing-masing faktor yang menjadi variable dalam penelitian ini. a. Informasi Asimetris (Asymmetric Information)

Dalam bidang ekonomi, informasi asimetri terjadi jika salah satu pihak dari suatu transaksi memiliki informasi lebih banyak atau lebih baik dibandingkan pihak lainnya. Informasi asimetri menurut Scoot dan O'Brien (2003) adalah frequently, one type of participant in the market (sellers, for example) will know something about the assets being traded the onather type of participant (buyers) does not know. When this situation exixts, the market is said to be characterized by information asymmetry [21].

Ada dua jenis asimetri informasi yaitu adverse selection dan moral hazard. Adverse selection terjadi karena beberapa orang seperti manajer perusahaan dan para pihak dalam (insider) lainnya mengetahui kondisi terkini dan prospek ke depan suatu perusahaan daripada para investor luar. Sedangkan moral hazard dapat terjadi karena adanya pemisahan kepemilikan dan pengendalian yang merupakan karakteristik kebanyakan perusahaan besar.

Pengukuran informasi asimetris dapat dilakukan berdasarkan tiga pendekatan utama, yaitu: berdasarkan analyst forecast, berdasarkan kesempatan berinvestasi, dan berdasarkan teori market microstruture

\section{b. Ukuran Perusahaan (Firm Size)}

Konsep ukuran perusahaan (firm size) menurut Brigham \& Houston (2012) merupakan ukuran besar kecilnya sebuah perusahaan yang ditunjukan atau dinilai oleh total asset, total penjualan, jumlah laba, beban pajak dan lain-lain [22]. Nuraina (2010) menyatakan bahwa ukuran perusahaan menggambarkan besar kecilnya suatu perusahaan yang dinyatakan dengan total aktiva atau total penjualan bersih [23].

Dengan demikian, ukuran perusahaan merupakan ukuran atau besarnya aset yang dimiliki oleh perusahaan. Menurut Rachmawati dan Pinem (2015) ukuran perusahaan menggambarkan besar kecilnya suatu perusahaan yang dapat dinyatakan dengan total aset atau total penjualan bersih [24]. Semakin besar total aset maupun penjualannya, maka semakin besar pula ukuran suatu perusahaan. Semakin besar aset, maka semakin besar modal yang ditanam. Sementara semakin banyak penjualan, maka semakin banyak juga perputaran uang dalam perusahan.

\section{c. Pengungkapan (Disclosure)}

Konsep disclosure menurut Evans (2003) berarti penyampaikan informasi dalam laporan keuangan, termasuk laporan keuangan itu sendiri, catatan atas laporan keuangan, dan pengungkapan tambahan yang berkaitan dengan laporan keuangan [25]. Laporan keuangan merupakan jendela informasi yang memungkinkan pihak di luar manajeman melihat kondisi perusahaan [26].

Disclousure menurut Darrough (1993) dikelompokkan menjadi dua, yaitu pengungkapan wajib dan pengungkapan sukarela [27]. Pengungkapan wajib (mandatory disclosure) adalah pengungkapan informasi yang diatur oleh badan pembuat standard dan regulator lainnya, aturan ini berupa persyaratan minimal pengungkapan yang harus dipenuhi oleh perusahaan publik. Sedangkan pengungkapan sukarela (voluntary disclosure) adalah pengungkapan diluar yang diwajibkan, merupakan pilihan bebas manajemen untuk memberikan informasi akuntansi dan informasi lainnya yang dipandang relevan sebagai dasar pengambilan keputusan para pemakai.

Salah satu tujuan disclousure menurut Belkaoui (2006) untuk memberikan informasi yang akan membantu investor dan kreditor menilai resiko [28]. Lebih lanjut, Kolb (2010) menjelaskan 
@ is The Best: Accounting Information Systems and Information Technology Business Enterprise

ISSN: 2252-9853 (Print) | ISSN: 2656-808X (Online)

manfaat yang diperoleh dari adanya disclousure adalah dapat mengurangi biaya transaksi dalam memperdagangkan surat berharga yang dikeluarkan perusahaan [29]. Seacar lebih luas lagi Hendriksen (1998), menjelaskan bahwa disclousure bermanfaat bagi beberapa pihak, antara lain: pemegang saham, investor, kreditor, dan pihak-pihak lainnya [30].

\section{Metode Penelitian}

Penelitian ini menggunakan metode deskriptif dan verifikatif dengan pendekatan kuantitatif. Metode deskriptif yang digunakan adalah metode yang dimulai dari mengumpulkan, menginventariskan, mengolah data hingga menyajikan hasil yang disertai dengan interpretasi sehingga diperoleh gambaran yang jelas tentang pokok permasalahan yang diteliti. Metode verifikatif digunakan dalam penelitian ini karena penelitian ini menguji secara sistematis dugaan adanya pengaruh antar variabel dari masalah yang diteliti.

Populasi yang digunakan dalam penelitian ini adalah perusahaan sub sektor properti dan real estate yang terdaftar di Bursa Efek Indonesia (BEI).

\section{Tabel 1. Proses Seleksi Sampel Penelitian}

\begin{tabular}{|c|l|c|}
\hline No & \multicolumn{1}{|c|}{ Indikator } & Jumlah Perusahaan \\
\hline 1. & $\begin{array}{l}\text { Perusahaan sub sektor properti dan real estate yang terdaftar di } \\
\text { Bursa Efek Indonesia tahun 2014 - 2016. }\end{array}$ & 45 \\
\hline 2. & Mengalami delisting selama periode penelitian. & $(26)$ \\
\hline 3. & $\begin{array}{l}\text { Perusahaan tidak memberikan laporan keuangan tahunan secara } \\
\text { periodik kepada Bursa Efek Indonesia selama periode penelitian }\end{array}$ & $(1)$ \\
\hline 4. & $\begin{array}{l}\text { Perusahaan tidak memiliki kelengkapan data yang dibutuhkan } \\
\text { dalam penelitian. }\end{array}$ & (4) \\
\hline & Total perusahaan yang dijadikan sampel & 14 perusahaan \\
\hline
\end{tabular}

Berdasarkan populasi yang memenuhi syarat, maka ukuran populasi adalah sebanyak 14 perusahaan. Adapun teknik penarikan sampel dilakukan dengan cara sensus atau seluruh anggota populasi dijadikan sampel. Periode penelitian dilakukan selama tiga tahun, sehingga ukuran data sampel seluruhnya adalah 42 sampel.

Data yang digunakan dalam penelitian ini adalah data panel yang bersumber dari laporan tahunan dan laporan keuangan industri properti BEI dengan periode 2014 sampai 2016 yang bersumber dari ICMD. Teknik analisis data untuk mencari faktor-faktor yang mempengaruhi cost of equity akan menggunakan model regresi berganda.

$$
Y_{i t}=\beta_{0}+\beta_{1} X_{1 i t}+\beta_{2} X_{2 i t}+\beta_{3} X_{3 i t}+\varepsilon_{i t}
$$

Keterangan:

$Y_{i t}$ : Variabel terikat (cost of equity) pada unit cross-section ke-i dan waktu ke-t

$X_{1 \mathrm{it}}$ : Informasi asimetris pada unit cross-section ke-i dan waktu ke-t

$X_{2 \mathrm{it}}$ : size perusahaan pada unit cross-section ke-i dan waktu ke-t

$X_{3 \mathrm{it}}$ : Disclosure Index pada unit cross-section ke-i dan waktu ke-t

$\beta_{0}$ : Nilai intercept (konstan)

$\beta_{1} \quad$ : Koefisien regresi $\mathrm{X}_{1}$

$\beta_{2}$ : Koefisien regresi $\mathrm{X}_{2}$

$\beta_{3}:$ Koefisien regresi $\mathrm{X}_{3}$ 
@is The Best: Accounting Information Systems and Information Technology Business Enterprise

ISSN: 2252-9853 (Print) | ISSN: 2656-808X (Online)

Sedangkan untuk melihat kontribusi faktor-faktor secara simultan akan menggunakan koefisien determinasi. Koefisien determinasi dinyatakan dalam persentase.

Untuk menguji pengaruh dari masing-masing faktor yang mempengaruhi cost of equity akan menggunakan uji t. Uji ini dilakukan untuk mengetahui pengaruh variabel bebas terhadap variabel terikat secara parsial. Langkah-langkah untuk uji $\mathrm{t}$ adalah sebagai berikut:

1) Menentukan hipotesis

a) Pengaruh informasi asimetris

$\mathrm{H}_{0.1}: \beta_{1}=0$ (informasi asimetris tidak berpengaruh terhadap cost of equity)

$\mathrm{H}_{1.1}: \beta_{1} \neq 0$ (informasi asimetris berpengaruh terhadap cost of equity)

b) Pengaruh ukuran perusahaan

$\mathrm{H}_{0.2}: \beta_{2}=0 \quad$ (ukuran perusahaan tidak berpengaruh terhadap cost of equity)

$\mathrm{H}_{1.2}: \beta_{2} \neq 0 \quad$ (ukuran perusahaan berpengaruh terhadap cost of equity)

c) Pengaruh disclosure

$\mathrm{H}_{0.3}: \beta_{3}=0 \quad$ (disclosure sukarela tidak berpengaruh terhadap cost of equity)

$\mathrm{H}_{1.3}: \beta_{3} \neq 0$ (disclosure sukarela berpengaruh terhadap cost of equity)

2) Menentukan tingkat signifikansi

Tingkat signifikansi yang digunakan dalam penelitian ini adalah sebesar 5\%. Hal ini berarti bahwa kemungkinan hasil penarikan kesimpulan merupakan hal yang benar memiliki probabilitas sebesar 95\%, atau memiliki tingkat toleransi kesalahan sebesar 5\%. Penggunaan tingkat signifikansi 5\% karena tingkat signifikansi ini umum digunakan pada penelitianpenelitian ilmu sosial serta dinilai telah cukup ketat dalam menguji hubungan-hubungan variabel yang dipilih.

3) Pengujian dilakukan dengan cara membandingkan besar p-value dengan $\alpha$ :

a) p-value $<\alpha=\mathrm{H}_{1}$ diterima, sehingga informasi asimetris, ukuran perusahaan, dan disclosure secara parsial berpengaruh terhadap cost of equity.

b) $\mathrm{p}$-value $\geq \alpha=\mathrm{H}_{1}$ ditolak, sehingga informasi asimetris, ukuran perusahaan, dan disclosure secara parsial tidak berpengaruh terhadap cost of equity.

Sedangkan untuk menguji kontribusi seluruh faktor yang mempengaruhi secara simultan menggunakan uji F. Pengujian ini digunakan untuk mengetahui pengaruh antara variabel bebas dan variabel terikat secara keseluruhan. Langkah pengujiannya sebagai berikut:

$H_{0}: \beta_{1}=\beta_{2}=\ldots=\beta_{p}=0 \quad:$ tidak terdapat pengaruh yang signifikan informasi asimetris, ukuran perusahaan, dan disclosure secara simultan terhadap cost of equity)

$H_{1}$ : minimal satu $\beta_{k} \neq 0 ; k=1,2,3$ : terdapat pengaruh yang signifikan dari informasi asimetris, ukuran perusahaan, dan disclosure secara simultan terhadap cost of equity)

Pengujian dilakukan dengan cara membandingkan besar $\mathrm{p}$-value dengan $\alpha$.

a) -value $<\alpha=H_{1}$ diterima, artinya informasi asimetris, ukuran perusahaan, dan disclosure berpengaruh secara simultan terhadap cost of equity.

b) p-value $\geq \alpha=H_{1}$ ditolak, artinya informasi asimetris, ukuran perusahaan, dan disclosure tidak berpengaruh secara simultan terhadap cost of equity. 


\section{Hasil dan Pembahasan Penelitian}

\section{Hasil Penelitian}

Biaya modal ekuitas (cost of equity) merupakan alat untuk mengukur biaya modal ekuitas suatu perusahaan. Cost of equity juga menggambarkan besaran return yang diharapkan dari investor pada saat mereka menginvestasikan dananya di suatu perusahaan. Jadi, cost of equity berarti identik dengan biaya kesempatan (opportunity cost) bagi investor. Cost of equity merupakan biaya penggunaan atas laba yang ditahan selama perusahaam masih memiliki laba ditahan, namaun cost of equity akan berubahn menjadi biaya saham biasa apabila perusahaan sudah kehabisan laba ditahan (return earning).

Ccost of equity berpeluang mengalami kenaikan secara internal dengan cara menggunakan laba yang diperoleh perusahaan atau secara eksternal dengan cara menerbitkan emisi saham biasa baru. Perusahaan sebenarnya dapat membagikan keuntungan dalam bentuk laba bersih setelah pajak yang diperoleh selama periode tertentu kepada para pemegang saham sebagai dividen atau menahannya dalam bentuk laba ditahan (return earning). Laba yang tidak dibagikan (ditahan) tersebut selanjutnya dipergunakan kembali oleh perusahaan untuk melakukan investasi. Return earning yang dipergunakan untuk investasi tersebut perlu dihitung biaya modalnya. Secara teoritis perusahaan yang menggunakan laba untuk reinvestasi harus memperoleh keuntungan minimal sebesar tingkat keuntungan jika pemegang saham menginvestasikan dananya ke dalam perusahaan dengan tingkat risiko yang sama. Hal ini karena keuntungan setelah pajak tersebut merupakan sebenarnya hak bagi pemegang saham biasa.

Ukuran cost of equity dalam penelitian ini di-proxy-kan dengan menggunakan CAPM. Model yang akan dibentuk dalam penelitian ini bahwa faktor-faktor yang mempengaruhi cost of equity, antara lain: informasi asimetris (asymmetric information), ukuran perusahaan (firm size), dan pengungkapan (disclousure). Ukuran informasi asimetris menggunakan spread yaitu alat yang digunakan untuk mengukur seberapa besar informasi asimetris yang terdapat pada perusahaan. Hal tersebut menggambarkan besar kecilnya ketidakseimbangan yang terjadi antara investor yang terinformasi. Ukuran besar kecilnya perusahaan dalam penelitian ini menggunakan log of total asset. Sedangkan ukuran pengungkapan dalam penelitian ini menggunakan disclosure index yaitu rasio untuk mengukur tingkat pengungkapan sukarela atas laporan tahunan yang dibuat oleh perusahaan. Dalam disclosure index terdapat beberapa item dari pengungkapan sukarela, perbandingan antara item yang diungkapkan dengan total item yang ada merupakan hasil dari disclosure index. Hasil dari disclosure index mencerminkan besarnya tingkat pengungkapan sukarela yang dilakukan perusahaan pada tahun tersebut.

Sebelum menentukan pengaruh dari masing-masing faktor, terlebih dahulu dilakukan uji data panel. Uji data panel dilakukan dengan menggunakan uji Hausman untuk menentukan apakah akan memilih fixed effects model atau random effects model. Hasil pengujian data panel dengan menggunakan uji Hausman adalah sebagai berikut:

\section{Tabel 2. Hasil Uji Hausman}

Correlated Random Effects - Hausman Test

Equation: Untitled

Test cross-section random effects

\begin{tabular}{lccc}
\hline \hline Test Summary & Chi-Sq. Statistic & Chi-Sq. d.f. & Prob. \\
\hline \hline Cross-section random & 15.033794 & 3 & 0.0018 \\
\hline \hline
\end{tabular}


@ is The Best: Accounting Information Systems and Information Technology Business Enterprise ISSN: 2252-9853 (Print) | ISSN: 2656-808X (Online)

Didapatkan nilai Prob. sebesar 0.0018 di mana nilai tersebut lebih kecil dari $\alpha$, maka model yang akan digunakan adalah fixed effects model.

Langkah selanjutnya dilakukan uji asumsi klasik untuk menentukan apakah dapat digunakan analisis regresi berganda atau tidak. Uji asumsi klasik terdiri dari uji normalitas, uji heteroskedastisitas, uji autokorelasi, dan uji multikolineritas. Adapun hasil pengujian yang dilakukan dinyatakan bahwa model analisis regresi berganda dapat digunakan.

\section{a. Analisis Regresi Berganda}

Penelitian ini menggunakan model regresi berganda. Berdasarkan pada hasil uji data panel, maka data yang digunakan menggunakan fixed effects model. Hasil pemodelannya sebagai berikut:

\section{Tabel 3. Fixed Effect Model Estimation}

Dependent Variable: COST

Method: Panel Least Squares

Date: 25/05/19 Time: 18:38

Sample: $2014-2016$

Periods included: 3

Cross-sections included: 14

Total panel (balanced) observations: 42

\begin{tabular}{crrrr}
\hline \hline Variable & Coefficient & Std. Error & t-Statistic & Prob. \\
\hline \hline C & 20.78770 & 6.271799 & 3.314471 & 0.0028 \\
ASYMMETRIC & 0.007679 & 0.004362 & 1.760291 & 0.0906 \\
FIRM SIZE & -1.693016 & 0.504560 & -3.355428 & 0.0025 \\
DISCLOSURE & 0.012075 & 0.004447 & 2.715359 & 0.0118 \\
\hline \hline
\end{tabular}

Berdasarkan tabel di atas maka didapatkan model regresinya sebagai berikut:

$$
Y=20,7877+0,007679 X_{1}-1,693016 X_{2}+0,012075 X_{3}
$$

Keterangan:

$Y=$ Cost of Equity

$X_{1}=$ Asymmetric Information

$X_{2}=$ Firm Size

$X_{3}=$ Disclosure

Berdasarkan persamaan regresi berganda di atas dapat diinterpertasikan sebagai berikut:

(1). Konstanta sebesar 20.7877 dapat diartikan bahwa jika keseluruhan variabel independen bernilai NOL maka cost of equity akan bernilai 20.7877 satuan.

(2). Jika informasi asimetris meningkat sebesar satu satuan dan variable lain dianggap konstan, maka akan meningkatkan nilai cost of equity sebesar 0.007679 satuan.

(3). Jika ukuran perusahaan meningkat sebesar satu satuan dan variable lain dianggap konstan, maka akan menurunkan nilai cost of equity sebesar 1.693016 satuan.

(4). Jika disclosure meningkat sebesar satu satuan dan variable lain dianggap konstan, maka akan meningkatkan nilai cost of equity sebesar 0.012075 satuan. 
@ is The Best: Accounting Information Systems and Information Technology Business Enterprise

ISSN: 2252-9853 (Print) | ISSN: 2656-808X (Online)

\section{b. Koefisien Determinasi (R2)}

Koefisien determinasi $\left(R^{2}\right)$ merupakan koefisien yang mengukur kemampuan variabelvariabel independen untuk memprediksi variabel dependen yang digunakan. Berikut hasil koefisien determinasi dari model yang terbentuk:

\section{Tabel 4. Koefisien Determinasi}

Effects Specification

\begin{tabular}{lllr}
\hline \hline Cross-section fixed (dummy variables) & & \\
\hline \hline R-squared & 0.593687 & Mean dependent var & 0.079148 \\
Adjusted R-squared & 0.333646 & S.D. dependent var & 0.127263 \\
S.E. of regression & 0.103885 & Akaike info criterion & -1.400332 \\
Sum squared resid & 0.269803 & Schwarz criterion & -0.696989 \\
Log likelihood & 46.40696 & Hannan-Quinn criter. & -1.142529 \\
F-statistic & 2.283053 & Durbin-Watson stat & 2.233530 \\
Prob(F-statistic) & 0.031171 & &
\end{tabular}

Hasil koefisien $\mathrm{R}^{2}$ sebesar 0.593687 atau $59.3687 \%$. Hal ini menunjukan bahwa asymmetric information, firm size, dan disclosure dapat memberikan kontribusi terhadap cost of equity sebesar $59.3687 \%$. Selain itu, $R^{2}$ juga menggambarkan kelayakan dari suatu model untuk digunakan. Model yang telah terbentuk merupakan model yang sudah layak digunakan karena memiliki $R^{2}$ lebih dari $50 \%$.

\section{c. Uji Hipotesis}

Uji t merupakan uji untuk mengetahui apakah variabel independen yang digunakan dalam penelitian berpengaruh signifikan secara individual (parsial) terhadap variabel dependen. Berikut hasil pengujian dari masing-masing variabel tersebut:

Tabel 5. Hasil Uji Hipotesis Parsial

\begin{tabular}{ccccc}
\hline Variable & Coefficient & Std. Error & t-Statistic & Prob. \\
\hline \hline C & 20.78770 & 6.271799 & 3.314471 & $\mathbf{0 . 0 0 2 8}$ \\
ASYMMETRIC & 0.007679 & 0.004362 & 1.760291 & $\mathbf{0 . 0 9 0 6}$ \\
FIRM SIZE & -1.693016 & 0.504560 & -3.355428 & $\mathbf{0 . 0 0 2 5}$ \\
DISCLOSURE & 0.012075 & 0.004447 & 2.715359 & $\mathbf{0 . 0 1 1 8}$ \\
\hline \hline
\end{tabular}

Berikut adalah hasil pengujian uji parsial pada setiap variabel independen terhadap variabel dependen:

(1). Variabel Informasi Asimetris (Asymmetric Information)

Prob. asymmetric information sebesar 0.0906 di mana nilai tersebut lebih besar dari $\alpha$ sebesar 0.05. Maka $\mathrm{H}_{1.1}$ ditolak, artinya asymmetric information tidak berpengaruh secara signifikan terhadap cost of equity.

(2). Variabel Ukuran Perusahaan (Firm Size)

Prob. firm size perusahaan sebesar 0.0025 di mana nilai tersebut lebih kecil dari $\alpha$ sebesar 0.05. Maka $\mathrm{H}_{1.2}$ diterima, artinya firm size berpengaruh secara signifikan terhadap cost of equity. 
(3). Variabel Pengungkapan (Disclosure)

Prob. disclosure sebesar 0.0118 di mana nilai tersebut lebih kecil dari $\alpha$ sebesar 0.05 . Maka $\mathrm{H}_{1.3}$ diterima, artinya disclosure berpengaruh secara signifikan terhadap cost of equity.

Uji F merupakan uji yang digunakan untuk mengetahui pengaruh ketiga variabel independen yaitu asymmetric information, size, dan disclosure secara bersamaan terhadap variabel dependen dalam penelitian ini yaitu cost of equity. Berikut hasil pengujian dari ketiga variabel tersebut:

Tabel 6. Hasil Uji Hipotesis Simultan

Effects Specification

\begin{tabular}{ll} 
Cross-section fixed (dummy variables) & \\
\hline \hline R-squared & 0.593687 \\
Adjusted R-squared & 0.333646 \\
S.E. of regression & 0.103885 \\
Sum squared resid & 0.269803 \\
Log likelihood & 46.40696 \\
F-statistic & 2.283053 \\
Prob(F-statistic) & 0.031171 \\
\hline \hline
\end{tabular}

Berdasarkan Tabel 5 diperoleh nilai Prob (F-statistic) sebesar 0.031171 di mana nilai tersebut lebih kecil dari $\alpha=0.05$. Maka $H_{1}$ diterima, artinya asymmetric information, firm size, dan disclosure secara simultan berpengaruh signifikan terhadap cost of equity.

\section{Pembahasan Penelitian}

Pembahasan hasil penelitian ini mengacu pada hasil pengujian hipotesis yang telah dilakukan. Berdasarkan hasil pengolahan data diperoleh informasi bahwa secara simultan variabel independen berpengaruh signifikan terhadap cost of equity. Secara parsial variabel informasi asimetris tidak berpengaruh signifikan terhadap cost of equity, sedangkan variabel ukuran perusahaan (size) dan variabel disclosure masing-masing berpengaruh signifikan terhadap cost of equity.

Pada dasarnya setiap perusahaan pasti memperhitungkan biaya yang terjadi dalam penggunaan modalnya. Dalam menggunakan ekuitas sebagai sumber modal, perusahaan perlu mengefisiensikan biaya yang terjadi nantinya. Hal tersebut dapat dilakukan dengan menurunkan cost of equity pada perusahaan. Terdapat beberapa faktor yang dapat mempengaruhi besar kecilnya cost of equity yang diantaranya tercermin dalam penelitian ini yaitu informasi asimetris, ukuran perusahaan, dan disclosure.

Penjelasan mengenai hasil penelitian akan dibahas dibawah ini:

a. Pengarub Informasi Asimetris terhadap Cost of Equity

Tingkat signifikansi yang digunakan dalam pengujian ini adalah $\alpha=5 \%$. Nilai probabilitas variable informasi asimetris adalah 0.0906 lebih besar dari nilai $\alpha=5 \%$ yang berarti variabel informasi asimetris bukan faktor yang mempengaruhi secara signifikan terhadap cost of equity. Nilai koefisien dari informasi asimetris berdasarkan persamaan regresi adalah sebesar 0.007679, hal ini menunjukkan bahwa setiap terjadi kenaikan 1 satuan pada nilai informasi asimetris, maka cost of equity akan meningkat sebesar 0.007679 satuan, dan sebaliknya. Walaupun terjadi perubahan pada nilau cost of equity pada saat variable informasi asimetris berubah, namun secara statistik 
@is The Best: Accounting Information Systems and Information Technology Business Enterprise ISSN: 2252-9853 (Print) | ISSN: 2656-808X (Online)

perubahan tersebut dianggap tidak signifikan. Dengan demikian, informasi asimetris tidak mendukung hipotesis dalam penelitian ini karena menunjukkan $H_{1}$ ditolak, sehingga variabel ini secara parsial tidak berpengaruh terhadap cost of equity.

Tingkat informasi asimetris yang diwakili oleh bid-ask spread tidak berpengaruh secara signifikan terhadap cost of equity. Besarnya informasi asimetris tidak dapat menjelaskan secara langsung pengaruhnya terhadap cost of equity. Hal ini dikarenakan investor tidak dapat membaca sinyal positif yang diberikan perusahaan, sehingga informasi terkait perusahaan tidak mempengaruhi besar atau kecilnya tingkat pengembalian yang diharapkan investor terhadap saham yang ditanam pada perusahaan.

Hasil penelitian ini tidak sesuai dengan penelitian terdahulu yang dilakukan oleh Komalasari dan Baridwan (2001), Gode dan Mohanram (2001), Mardiyah (2002), Pratt dan Grabownski (2010), Murwaningsari (2012), serta Indayani (2013) yang menyatakan bahwa informasi asimetris berpengaruh positif dan signifikan terhadap cost of equity. Namun hal tersebut sejalan dengan penelitian yang dilakukan oleh Albanez, et al. (2010) dan Ningsih dan Ariani (2016) yang menyatakan bahwa asimetri informasi idak berpengaruh terhadap biaya modal ekuitas.

\section{b. Pengarub Ukuran Perusabaan terbadap Cost of Equity}

Nilai koefisien dari ukuran perusahaan berdasarkan persamaan regresi adalah sebesar 1.693016 dan memiliki pengaruh yang signifikan pada tingkat kepercayaan 95\%. Hal ini menunjukkan bahwa setiap terjadi kenaikan 1 satuan pada nilai ukuran perusahaann maka cost of equity akan menurun sebesar 1.693016 satuan, hal tersebut sudah sesuai dengan hipotesis awal dalam penelitian ini.

Hasil penelitian ini didukung oleh penelitian sebelumnya yaitu penelitian yang dilakukan oleh Komalasari dan Baridwan (2001), Omran dan Pointon (2004), Pratt dan Gabownski (2010), Albanez, et al.(2010) serta Murwaningsari (2012) yang menunjukkan bahwa terdapat pengaruh negatif ukuran perusahaan terhadap cost of equity. Pada penelitian sebelumnya menunjukkan pada perusahaan besar dengan total risiko yang ditanggung oleh investor lebih besar, akan mendapatkan keuntungan per saham tertentu sesuai dengan risiko yang ditanggung.

Dari hasil temuan empiris dalam penelitian ini, mengimplikasikan adanya kecenderungan investor lebih senang menanamkan modal pada perusahaan besar sebab perusahaan besar memiliki cost of equity yang kecil dibandingkan dengan perusahaan kecil. Hal ini membuktikan bahwa perusahaan properti berukuran besar yang go public di Indonesia memiliki daya serap pasar yang lebih besar daripada perusahaan properti berukuran kecil. Perusahaan besar yang go public di Indonesia memiliki jumlah pemegang saham (shareholder) yang lebih besar dibandingkan perusahaan yang berukuran kecil. Peruhsaaan besar juga lebih banyak melakukan aktivitas yang banyak memberikan dampak untuk masyarakat.

\section{c. Pengaruh Disclosure terhadap Cost of Equity}

Disclosure memiliki nilai koefisien berdasarkan persamaan regresi yaitu sebesar 0.012075 dan memiliki hubungan yang signifikan pada tingkat kepercayaan 95\%. Hal ini menunjukkan bahwa setiap terjadi kenaikan 1 satuan pada nilai disclosure maka cost of equity akan meningkat sebesar 0.012075 satuan. Dalam rancangan pengujian hipotesis disebutkan bahwa disclosure berpengaruh terhadap cost of equity perusahaan, dalam penelitian ini prob. disclosure dinyatakan sebesar $0.0118 \mathrm{di}$ mana nilai tersebut lebih kecil dari $\alpha$ sebesar 0.05 , maka $\mathrm{H}_{1.3}$ diterima. Artinya disclosure berpengaruh positip signifikan terhadap cost of equity. Dari hasil tersebut dapat ditarik kesimpulan 
@is The Best: Accounting Information Systems and Information Technology Business Enterprise ISSN: 2252-9853 (Print) | ISSN: 2656-808X (Online)

bahwa tingkat disclosure berpengaruh terhadap cost of equity, artinya semakin banyak perusahaan yang mengungkapkan mengenai jati diri dan identitas perusahaan maka akan semakin besar cost of equity yang dikeluarkan perusahaan.

Hasil penelitian ini sejalan dengan penelitian terdahulu yang dilakukan oleh Botosan (1997), Gode dan Mohanram (2001), Mardiyah (2002), Pratt dan Grabownski (2010), serta Murwaningsari (2012) yang menunjukkan bahwa disclosure mempunyai pengaruh terhadap cost of equity perusahaan. Namun, hasil penelitian ini bertolak belakang dengan hasil penelitian Ningsih an Ariani (2012) yang menyatakan bahwa disclousure tidak berpengaruh terhadap cost of equity.

\section{d. Pengaruh Simultan Variabel Independen terhadap Cost of Equity}

Berdasarkan tabel 4 dapat diketahui bahwa nilai probabilitas pada uji-F lebih kecil dari tingkat signifikansi 5\%. Besarnya nilai $\mathrm{R}^{2}$ adalah sebesar 0.593687 artinya cost of equity dipengaruhi oleh informasi asimetris, ukuran perusahaan, dan disclosure sebesar $59.3687 \%$, sedangkan sebesar $40.6313 \%$ dipengaruhi oleh faktor-faktor lain yang mempengaruhi cost of equity diluar variabel independen yang diteliti. Faktor-faktor di luar yang diteliti tersebut seperti yang dijelaskan Pratt dan Grabownski (2010) yaitu industry risk, volatily of return, leverage, dan other company specific faktor. Sedangkan menurut Gode dan Mohanram (2001) faktor-faktor tersebut seperti return volatility, leverage, industry effect, dan earning volatility.

\section{Penutup}

Berdasarkan hasil penelitian dan pembahasan terdapat beberapa kesimpulan. Pertama, faktor-faktor yang mempengaruhi cost of equity adalah ukuran perusahaan (firm size) dan pengungkapan (disclousure). Ukuran perusahaan berpengaruh negatif signifikan terhadap cost of equity perusahaan properti dan real estate. Disclosure memiliki pengaruh positif terhadap cost of equity perusahaan properti dan real estate. Sedangkan informasi asimetris tidak berpengaruh terhadap cost of equity perusahaan properti dan real estate. Kedua, informasi asimetris, ukuran perusahaan, dan disclosure secara simultan berpengaruh terhadap cost of equity perusahaan properti dan real estate. Untuk penelitian selanjutnya, bisa dimasukkan faktor-faktor lainnya yang tidak diteliti dalam penelitian ini. Sedangkan untuk unit analisisnya bias dilakukan untuk semua kelompok industri yang ada di Bursa Efek Indonesia.

\section{DAFTAR PUSTAKA}

[1]. Loveridge, Scott. "A typology and assessment of multi-sector regional economic impact models." Régional studies 38.3 (2004): 305-317.

[2]. Nazir, Mian Sajid, and Talat Afza. "Impact of aggressive working capital management policy on firms' profitability." IUP Journal of Applied Finance 15.8 (2009): 19.

[3]. Fatmawati, Mila. "Penggunaan the Zmijewski Model, the Altman Model, dan the Springate Model sebagai prediktor delisting." Jurnal Kenangan dan Perbankan 16.1 (2012).

[4]. Botosan, Christine A. "Disclosure level and the cost of equity capital." Accounting review (1997): 323-349.

[5]. Titman, S., Keown, A. J., Martin, J. D., \& Martin, T. Financial management: Principles and applications (Vol. 11). Boston: Prentice Hall. 2011.

[6]. Gode, Dhananjay Dan K., and Partha S. Mohanram. "What affects the implied cost of equity capital?." What Affects the Implied Cost of Equity Capital (2001). 
@ is The Best: Accounting Information Systems and Information Technology Business Enterprise ISSN: 2252-9853 (Print) | ISSN: 2656-808X (Online)

[7]. Pratt, Shannon P., and Roger J. Grabowski. Cost of capital: workbook and technical supplement. John Wiley \& Sons, 2010.

[8]. Komalasari, Puput Tri, and Zaki Baridwan. "Asimetri Informasi dan Cost of equity capital." The Indonesian Journal of Accounting Research 4.1 (2001).

[9]. Mardiyah, Aida Ainul. "Pengaruh informasi asimetri dan disclosure terhadap cost of capital." The Indonesian Journal of Accounting Research 5.2 (2002).

[10]. Murwaningsari, Etty. "FAKTOR-FAKTOR YANG MEMPENGARUHI COST OF CAPITAL.(Pendekatan: Structural Equation Model)." Jurnal Ekonomi dan Bisnis Airlangga (JEBA) | Journal of Economics and Business Airlangga 22.2 (2012).

[11]. Omran, Mohammed, and John Pointon. "The determinants of the cost of capital by industry within an emerging economy: evidence from Egypt." International Journal of Business 9.3 (2004).

[12]. Albanez, Tatiana, et al. "The Relationship of Asymmetric Information, Financing Decisions and Cost of Capital in Brazilian Public Companies." Review of Business 31.1 (2010).

[13]. Indayani, Dewi Mutia. "Pengaruh informasi asimetri dan voluntary disclosure terhadap cost of capital pada perusahaan manufaktur yang terdaftar di Bursa Efek Indonesia." Jurnal Reviu Akuntansi dan Keuangan 3.1 (2013).

[14]. Ningsih, Rini Dwiyuna, and Nita Erika Ariani. "Pengaruh asimetri informasi, pengungkapan modal intelektual, dan kualitas audit terhadap biaya modal ekuitas (studi pada perusahaan LQ 45 yang terdaftar di Bursa Efek Indonesia tahun 2012-2014)." Jurnal Ilmiah Mahasiswa Ekonomi Akuntansi 1.1 (2016): 149-157.

[15]. Modigliani, Franco, and Merton Miller. "The Cost of Capital, Corporate Finance, and the Theory of Corporation Finance." American Economic Review 48 (1958): 261-297.

[16]. Ross, S., Westerfield, R., \& Jaffe, J. (2012). Corporate finance. McGraw-Hill Higher Education.

[17]. Copeland, Thomas E., John Fred Weston, and Kuldeep Shastri. Financial theory and corporate policy. Vol. 3. Reading, MA: Addison-Wesley, 1988.

[18]. Fred Weston, J., and Eugene F. Brigham. Managerial finance. Dryden Press, 1977.

[19]. Utami, Wiwik. "Pengaruh manajemen laba terhadap biaya modal ekuitas (studi pada perusahaan publik sektor manufaktur)." The Indonesian Journal of Accounting Research 9.2 (2006).

[20]. Botosan, Christine A., and Marlene A. Plumlee. "A re-examination of disclosure level and the expected cost of equity capital." Journal of accounting research 40.1 (2002): 21-40.

[21]. Scott, William Robert, and Patricia C. O'Brien. Financial accounting theory. Vol. 3. Toronto: Prentice Hall, 2003.

[22]. Brigham, Eugene F., and Joel F. Houston. Fundamentals of financial management. Cengage Learning, 2012.

[23]. Nuraina, Elva. Pengaruh kepemilikan institusional dan ukuran perusahaan terhadap kebijakan hutang dan nilai perusabaan (Studi Pada Perusabaan Manufaktur yang Tercatat di BEI). Diss. UNS (Sebelas Maret University), 2010.

[24]. Rachmawati, Dwi, and Dahlia Br Pinem. "Pengaruh profitabilitas, leverage dan ukuran perusahaan terhadap nilai perusahaan." Equity 18.1 (2015): 1-18.

[25]. Evans, Thomas G. Accounting theory: Contemporary accounting issues. South-Western Pub, 2003.

[26]. Nugraheni, Aprilia. Analisis Ketepatan Prediksi Potensi Kebangkerutan Melalui Altman Z-Score dan Hubungannya dengan Harga Saham pada Perusabaan Perbankan yang Listing di Bursa Efek Jakarta. Diss. Universitas Negeri Semarang, 2005.

[27]. Darrough, Masako N. "Disclosure policy and competition: Cournot vs. Bertrand." Accounting review (1993): 534-561. 
@ is The Best: Accounting Information Systems and Information Technology Business Enterprise ISSN: 2252-9853 (Print) | ISSN: 2656-808X (Online)

[28]. Belkaoui, Ahmed Riahi. "Accounting Theory Edisi 5." Yulianto, AA dan Demauli, R.(Penerjemah). Teori Akuntansi. Penerbit Salemba Empat, Jakarta (2006).

[29]. Kolb, Robert W. "Disclosure's failure in the subprime mortgage crisis." Lessons from the Financial Crisis (2010): 443.

[30]. Hendrickson, Harvey. "Relevant financial reporting questions not asked by the accounting profession." Critical Perspectives on Accounting 9.5 (1998): 489-505. 